\title{
ANALISIS DINAMIS KETERKAITAN VARIABEL YANG MEMPENGARUHI NERACA TRANSAKSI BERJALAN INDONESIA TAHUN 2012
}

\author{
Winta Ratna Sari \\ Mahasiswa PPs Ilmu Ekonomi Unimed \\ Email: winta.ratnasari@yahoo.co.id
}

\begin{abstract}
This study was to analyze the contribution rate (the rupiah against the U.S. dollar), Libor Interest Rate, Inflation and Output Growth (GDP) of the current account balance in Indonesia. The data used in this study secondary data is sourced from Indonesia Financial Statistics. The data used is the data quarterly from the first quarter of 2000 up to 2010 fourth quarter. The results of the estimated Vector Autoregression (VAR) indicates that there is a relationship between the Current Account, Exchange Rate, Libor Interest Rate, Inflation and GDP at lag $t$-1. Impulse response function of the stability of the first note that all variables are in the long run that is over 5 years and tend to be stable. This means that in the short term variables that are used do not provide a meaningful contribution in the long term but will mutually contribute to each other. Variance Decomposition Based on these results, it is known that all variables contributed to the Current Account, but his greatest contribution is of the variable itself, this means that the current account tends to a variable receiving contributions rather than giving contributions
\end{abstract}

Key words: Current Account, Libor Interest Rates, Exchange Rates, Inflation and GDP

\section{PENDAHULUAN}

7 erekonomian global yang terjadi saat ini sebenarnya merupakan perkembangan dari proses perdagangan internasional. Indonesia yang ikut serta dalam Perdagangan internasional berupaya agar kegiatan tersebut dapat memberikan kontribusi terhadap pertumbuhan ekonomi. Untuk mengetahui seberapa besar kontribusi perdagangan internasional yang telah dilakukan bangsa ini, kita dapat melihat nya melalui sebuah laporan yang disebut sebagai Neraca Pembayaran. Neraca pembayaran merupakan suatu ikhtisar yang meringkas transaksi-transaksi antara penduduk suatu negara dengan penduduk negara lain selama jangka waktu tertentu (biasanya satu tahun). Neraca pembayaran mencakup pembelian dan penjualan barang dan jasa, hibah dari individu dan pemerintah asing, serta transaksi finansial. Umumnya neraca pembayaran terbagi atas neraca transaksi berjalan, neraca lalu lintas modal dan finansial, dan item-item finansial.

Neraca pembayaran Indonesia memainkan peranan sangat penting dalam pengelolaan ekonomi makro Indonesia, selain dapat di jadikan barometer dalam mengukur 
kemampuan perekonomian nasional dalam menopang transaksi-transaksi internasional terutama yang berhubungan dengan kewajiban pembayaran utang, transaksi ekspor dan impor, posisi neraca pembayaran juga merupakan salah satu indikator yang mempengaruhi sentiment para pelaku pasar, disamping itu sejumlah besaran yang ada didalamnya seperti transaksi ekspor dan impor barang dan jasa memiliki peranan yang penting dalam pembentukan Produk Domestik Bruto, yang pada akhirnya mempengaruhi Pertumbuhan Ekonomi.

Salah satu komponen dari neraca pembayaran adalah Neraca Transaksi Berjalan. “ Neraca Transaksi Berjalan merupakan komponen dari Neraca pembayaran yang mencatat neraca perdagangan, neraca jasa, pendapatan atas investasi dan transaksi unilateral." ( Tambunan , $2001: 127$ ).

Neraca transaksi berjalan terdiri dari neraca perdagangan yang mencatat ekspor (X) dan impor (M) komoditi dan neraca bersih, serta transfer. Neraca modal terdiri dari investasi langsung luar negeri dan pembelian saham, obligasi dan transaksi bank yang menyebabkan aliran modal ke luar negeri (Kreinin, 2002:215). Pada Neraca Pembayaran Indonesia Periode 2000 sampai dengan 2010 sebagaimana terlihat pada Gambar 1 berada dalam kondisi surflus, dan mengalami kenaikan yang berfluktuasi. Terlihat pada tahun 2000 neraca transaksi berjalan menunjukkan jumlah \$ 7.991 juta dan jumlah ini lebih rendah dari tahun sebelumnya sebesar \$ 1.090 juta. Ini disebabkan terjadi penurunan surplus perdagangan migas dan non migas. Ditahun 2002 dan 2003 neraca transaksi berjalan mengalami kenaikan masing masing $\$ 7.822$ juta dan $\$ 8.106$ juta, karena naiknya neraca perdagangan dari kenaikan ekspor migas dan non migas. Di tahun 2004 neraca transaksi berjalan kembali mengalami penurunan sebesar \$ 4.998 juta, hal ini dikarenakan nilai ekspor yang menurun dari nilai impor.

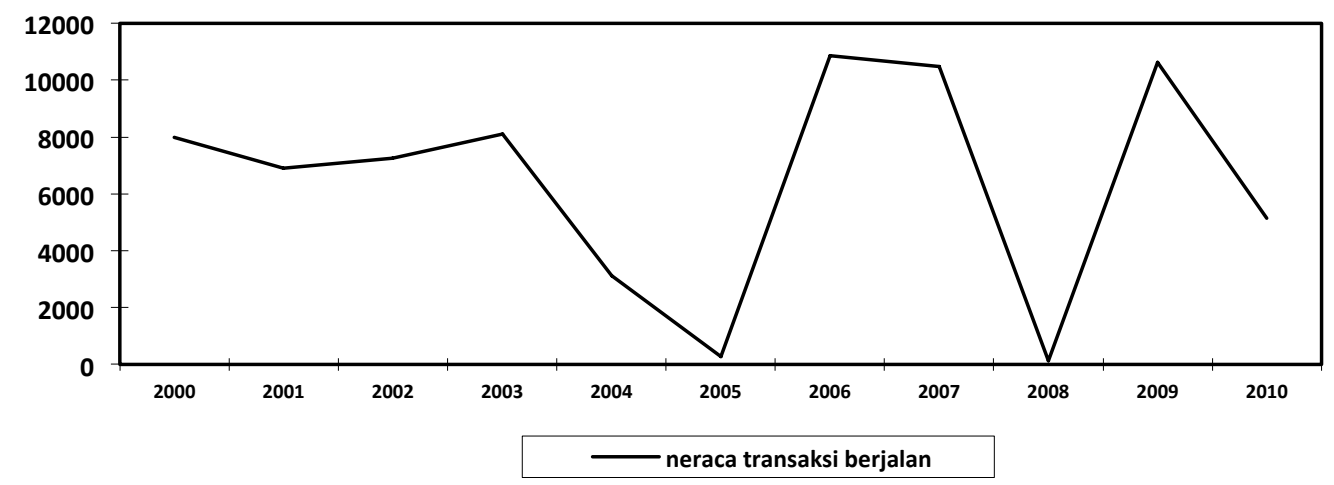

Sumber : Laporan Tahunan 2000 - 2011 Bank Indonesia (diolah)

Gambar 1. Transaksi Berjalan Dari tahun 2000 - 2010 ( dalam Juta US \$ )

Pada tahun 2005 jumlah neraca transaksi berjalan kembali mengalami penurunan yang cukup tajam sebesar $\$ 2.902$ juta dari tahun 2004. Penurunan di tahun 2005 disebabkan oleh penurunan kinerja transaksi berjalan migas. Defisit transaksi berjalan migas disumbang oleh penurunan neraca perdagangan (trade balance) setelah impor migas tumbuh lebih tinggi dibandingkan ekspor migas, sehingga surplus neraca perdagangan menurun dan peningkatan defisit transaksi jasa migas. Kinerja transaksi 
berjalan yang secara keseluruhan menurun tidak terlepas dari pengaruh melonjaknya harga minyak dunia.

Di tahun 2006 dan 2007 neraca transaksi berjalan kembali menunjukkan kemajuan dengan menunjukkan peningkatan yang luar biasa dari tahun 2005 yaitu sebesar \$ 10.781 juta . Hal ini di karenakan oleh perkembangan ekonomi global selama 2006 yang kondusif, khususnya tercermin pada kenaikan permintaan dunia dan harga komoditas, cukup besar pengaruhnya terhadap peningkatan ekspor Indonesia. Sebagai respons terhadap perkembangan ekonomi global tersebut, volume ekspor pada sebagian besar komoditas juga mengalami peningkatan.

Namun di tahun 2008 terjadi penurunan transaksi berjalan yang cukup tajam sebesar $\$ 10.365$ juta, dengan jumlah neraca transaksi berjalan hanya \$ 126 juta, dikarenakan memburuknya pasar finansial global, melambatnya pertumbuhan ekonomi dunia dan turunnya harga komoditas global. Memburuknya pasar financial global mendorong aliran modal ke emerging countries semakin rentan terhadap terjadinya arus pembalikan (capital reversal). Tendensi perlambatan pertumbuhan ekonomi global yang terus berlangsung tidak terlepas dari semakin kuatnya imbas perlambatan ekonomi negara maju terhadap tingkat pertumbuhan Negara berkembang. Sebagai akibat, tingkat pertumbuhan Negara berkembang yang relatif masih tinggi tidak dapat lagi menopang pertumbuhan ekonomi global sebagaimana tahun sebelumnya. Seiring dengan semakin lemahnya pertumbuhan ekonomi, permintaan komoditas juga semakin menurun sehingga mendorong turunnya berbagai harga komoditas di pasar global.

Neraca transaksi berjalan pada tahun 2009 mencatat kenaikan sebesar \$10.502 juta. Peningkatan ini didukung oleh kinerja ekspor, yang meskipun mengalami kontraksi akibat penurunan pertumbuhan ekonomi global, tercatat tidak sebesar kontraksi pada impor. Kinerja ekspor juga ditopang oleh ekspor manufaktur pada akhir tahun 2009 sejalan dengan semakin cepatnya pemulihan ekonomi negara maju terutama di AS dan Jepang. Sementara itu, impor melambat cukup signifikan terutama dipengaruhi oleh menurunnya permintaan domestik sejalan dampak perlambatan pertumbuhan ekonomi domestik. Dan di tahun 2010 transaksi berjalan menyusut kembali sebesar \$ 5.482 juta di sebabkan karena kenaikan surplus neraca perdagangan nonmigas dan gas yang terjadi pada tahun 2010 lebih sedikit dibandingkan dengan kenaikan defisit neraca perdagangan minyak dan neraca pendapatan. Untuk lebih jelasnya perhatikan Tabel 1 yang menunjukkan jumlah Neraca transaksi berjalan, nilai tukar rata-rata Rupiah terhadap \$ US, suku bunga Libor dan Inflasi (IHK) di Indonesia sejak 2000 sampai dengan 2010.

Tabel 1. Neraca transaksi Berjalan, Nilai Tukar rata-rata Rp/\$ US, suku bunga LIBOR, dan IHK selama $2000-2010$

\begin{tabular}{crrrr}
\hline Tahun & $\begin{array}{c}\text { Neraca transaksi Berjalan } \\
\text { ( Juta US \$) }\end{array}$ & $\begin{array}{c}\text { Nilai Tukar rata2 } \\
\text { RP terhadap \$ }\end{array}$ & $\begin{array}{c}\text { Suku bunga } \\
\text { Libor (\%) }\end{array}$ & $\begin{array}{c}\text { Inflasi/ IHK } \\
(\%)\end{array}$ \\
\hline 2000 & 7.991 & 8.403 & 6.2 & 9.35 \\
\hline
\end{tabular}




\begin{tabular}{rrrrr}
\hline 2001 & 6.901 & 10.255 & 1.98 & 12.55 \\
2002 & 7.262 & 9.318 & 1.38 & 10.1 \\
2003 & 8.106 & 8.572 & 1.22 & 5.1 \\
2004 & 3.108 & 8.940 & 2.78 & 6.4 \\
2005 & 278 & 9.713 & 4.7 & 17.1 \\
2006 & 10.859 & 9.020 & 5.37 & 6.6 \\
2007 & 10.491 & 9.419 & 4.6 & 6.59 \\
2008 & 126 & 10.950 & 1.75 & 11.06 \\
2009 & 10.682 & 9.400 & 0.43 & 2.78 \\
2010 & 5.146 & 8.991 & 0.46 & 6.96 \\
\hline
\end{tabular}

Sumber : Laporan Tahunan 2000 - 2010 Bank Indonesia (diolah)

Menurut Krugman dan Obstfeld (1999; 78), ada dua faktor utama yang mempengaruhi saldo transaksi berjalan yaitu kurs riil mata uang domestik terhadap mata uang asing dan pendapatan bersih domestik. Faktor tersebut merupakan faktor yang mempengaruhi secara langsung, sedang pada kenyataannya banyak faktor lain yang secara tidak langsung berpengaruh terhadap neraca transaksi berjalan seperti variabel neraca fiskal, investasi domestik maupun pengeluaran pemerintah.

Pada Gambar 2 terlihat kondisi nilai tukar dengan neraca transaksi berjalan selama 2000 - 2010, tidak selamanya nilai tukar berhubungan negatif dengan neraca transaksi berjalan di Indonesia seperti kondisi nilai tukar dengan transaksi berjalan pada tahun 2007 dimana nilai tukar rata-rata Rupiah terhadap \$ US berada pada posisi Rp. 9.140,00. turun sebesar 36 rupiah dari tahun sebelumnya dan neraca transaksi berjalan juga turun dari 10.859 juta \$ US menjadi 10.429 juta \$ US. Kondisi ini tidak sesuai dengan teori bahwa nilai tukar berhubungan negatif dengan neraca transaksi berjalan.

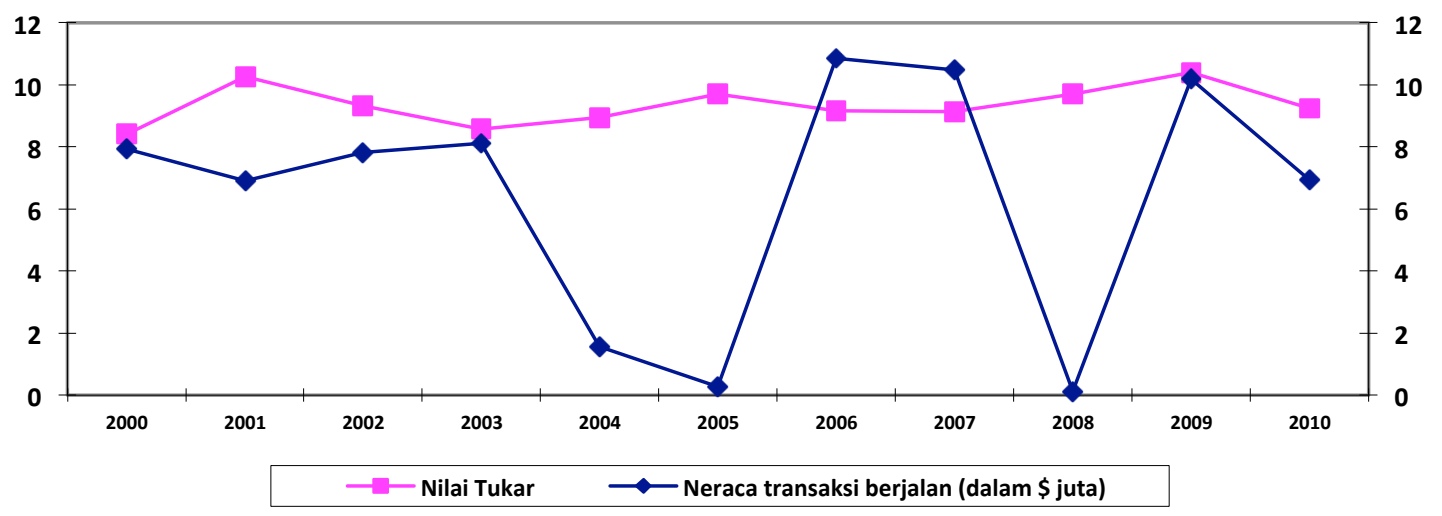

Sumber : Laporan Tahunan 2000 - 2010 Bank Indonesia (diolah)

Gambar 2. Tren Nilai Tukar (Rp/\$) dan Neraca transaksi berjalan $2000-2010$

Depresiasi nilai tukar yang tajam setelah perubahan sistem nilai tukar dari sistem nilai tukar mengambang terkendali (managed floating exchange rate) ke sistem nilai tukar mengambang bebas (free floating exchange rate) merubah posisi neraca transaksi berjalan Indonesia yang sebelumnya selalu mengalami defisit menjadi surplus. Awal depresiasi rupiah yang sangat besar sejak diberlakukanya free floating exchange rate memperparah defisit neraca transaksi berjalan di Indonesia. Kemudian, neraca transaksi berjalan menunjukkan posisi surplus dua kuartal setelah mengalami 
depresiasi yang sangat besar. Hal ini menunjukkan adanya keterkaitan antara nilai tukar dengan neraca transaksi berjalan. (Darwanto , $2007: 16$ ).

Setiap terjadi tekanan nilai tukar Rupiah sebagai efek kebijakan moneter akan disesuaikan melalui pengaruh suku bunga terhadap aliran modal dan pengaruh perubahan nilai tukar Rupiah terhadap penawaran ekspor dan permintaan impor. Melalui mekanisme demikian, neraca transaksi berjalan berfungsi sebagai alat mekanisme penyesuaian yang penting sehingga overall Balance of Payment (BOP) selalu dalam ekuilibrium. Dengan demikian, kebijakan moneter dalam sistem nilai tukar Rupiah yang fleksibel secara teori memerlukan sensivitas yang tinggi antara suku bunga domestik terhadap aliran modal internasional dan keeratan hubungan negatif antara nilai tukar Rupiah dengan suku bunga serta elatisitas yang tinggi antara perubahan nilai tukar Rupiah dengan penawaran ekspor dan permintaan impor. Selain itu, nilai tukar Rupiah yang fleksibel dan stabil juga harus tetap dijaga agar tidak memberikan tekanan pada harga-harga domestik. Oleh karena suku bunga tampak memegang peranan vital dalam pengendalian moneter dalam sistem nilai tukar yang fleksibel, maka pendekatan pengendalian moneter diusulkan untuk menggunakan suku bunga sebagai sasaran operasional dengan inflasi sebagai sasaran tunggal. Suku bunga dalam jangka panjang, baik suku bunga domestik (SBI) maupun suku bunga internasional (LIBOR) memberikan pengaruh negatif namun tidak signifikan terhadap neraca perdagangan (BOP). (Yusuf, $2007: 53$ ).

Pada Gambar 3 berikut disajikan hubungan antara suku bunga (LIBOR 6 bulan USD dalam \%) dengan neraca transaksi berjalan/PDB (dalam \%).

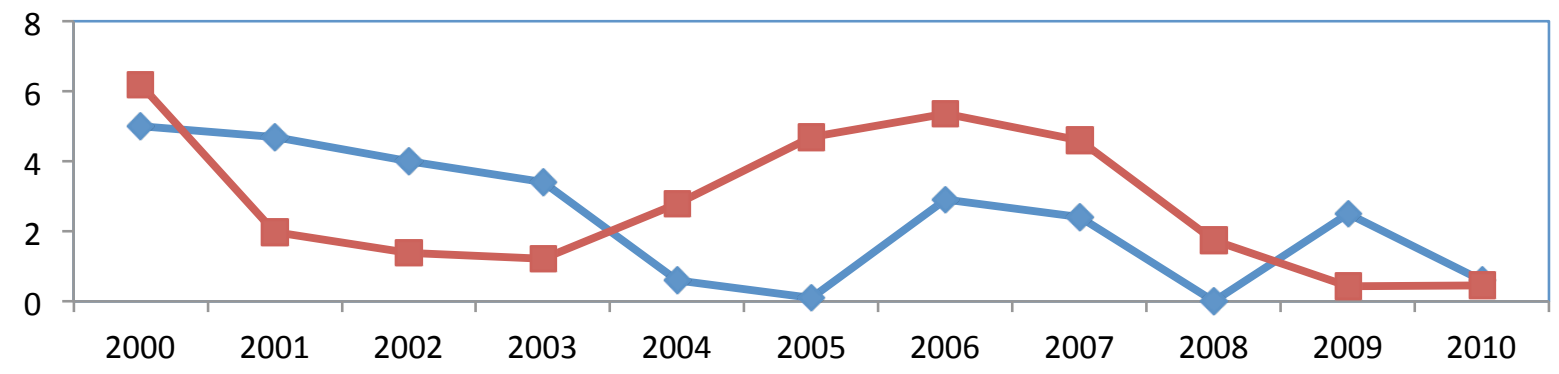

Gambar 3.Tren suku bunga LIBOR 6 bulan USD (dalam \%) dan neraca transaksi berjalan/PDB (dalam \%)

Di sisi lain inflasi merupakan gejala ekonomi yang sangat menarik untuk diperhatikan. Setiap kali ada gejolak sosial, politik, dan ekonomi didalam maupun diluar negri, masyarakat akan selalu mengaitkannya dengan masalah inflasi. Secara langsung inflasi memang tidak mempengaruhi neraca transaksi berjalan, namun berpengaruh terhadap neraca pembayaran.

Inflasi memiliki keterkaitan dengan neraca pembayaran . Inflasi tinggi menyebabkan harga barang impor lebih murah dari pada barang yang diproduksi didalam negeri. Dan oleh karena itu, inflasi akan memuat impor berkembang lebih cepat dibandingkan dengan ekspor. Disamping itu aliran modal keluar akan lebih banyak dari pada yang 
masuk kedalam negeri (Nasaruddin , $2002: 2$ ).Demikian pula dengan Pertumbuhan ekonomi kaitannya dengan neraca transaksi berjalan, dimana pertumbuhan ekonomi yang digambarkan dalam GDP (Pendapatan riil) menunjukkan kemampuan konsumen domestik dalam membeli barang barang konsumsi. Oleh karena itu, kenaikan pendapatan domestik akan menyebabkan meningkatnya belanja masyarakat terhadap barang-barang, termasuk barang impor suatu Negara, yang akan memperburuk kondisi neraca transaksi berjalan. Sebaliknya , jika pendapatan domestik turun maka belanja terhadap barang-barang termasuk barang impor suatu Negara akan turun. ( Murti , $2007: 4$ ).

Lebe, et al ( 2009 : 77 ) mengemukakan bahwa pertumbuhan ekonomi merupakan salah satu penyebab terjadinya defisit neraca transaksi berjalan yang merupakan perbedaan jumlah tabungan nasional dan investasi. Pertumbuhan ekonomi dapat meningkatkan investasi dan menurunkan tabungan, penurunan tabungan ini menyebabkan defisit anggaran, sehingga dalam jangka pendek pertumbuhan ekonomi tidak mempengaruhi neraca transaksi berjalan, namun dalam jangka panjang pertumbuhan ekonomi akan membawa dampak terhadap defisit neraca transaksi berjalan.. Hubungan antara transaksi berjalan dengan pertumbuhan ekonomi dan inflasi seperti terlihat pada Gambar 4.

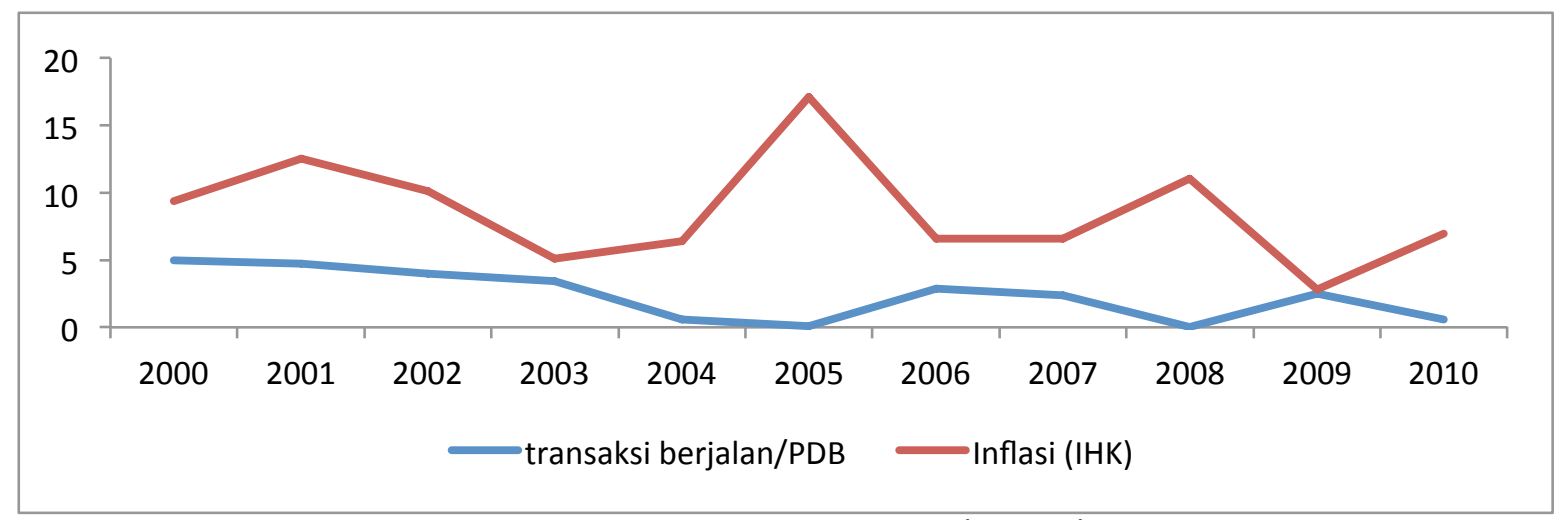

Sumber : Laporan Tahunan 2000 - 2010 Bank Indonesia (diolah)

Gambar.4. Hubungan Neraca transaksi Berjalan/PDB dan Inflasi (dalam\%)

\section{METODOLOGI}

Untuk mengidentifikasi pengaruh variable-variabel yang digunakan dalam penelitian ini, maka digunakam metode VAR (Vector Autoregression). Penelitian ini akan mengamati lima variabel endogen yaitu Neraca transaksi Berjalan (NTB), Nilai Tukar riil US \$ terhadap Rupiah ( NT ), Tingkat Inflasi (P), Pertumbuhan Ekonomi/GDP ( PDB ), dan Suku bunga ( SBL) , di Indonesia maka hubungan interdependens antara kelima variabel tersebut dispesifikasikan ke dalam sistem persamaan yang terdiri dari lima persamaan berikut:

$$
\begin{aligned}
& \mathrm{NTB}_{\mathrm{t}}={ }_{1}+\sum_{j=1}^{k} 1 \mathrm{jNTB}_{\mathrm{t}-\mathrm{j}}+\sum_{j=1}^{k} 1 \mathrm{jNT}_{\mathrm{t}-\mathrm{j}}+\sum_{j=1}^{k} 1 \mathrm{jP}_{\mathrm{t}-\mathrm{j}}+\sum_{j=1}^{k} 1 \mathrm{jPDB}_{\mathrm{t}-1}+\sum_{j=1}^{k} 1 \mathrm{jSBL}_{\mathrm{t}-1}+ \\
& \mathrm{NT}_{\mathrm{t}}={ }_{2}+\sum_{j=1}^{k} 2 \mathrm{jNT}_{\mathrm{t}-\mathrm{j}}+\sum_{j=1}^{k} 2 \mathrm{jP}_{\mathrm{t}-\mathrm{j}}+\sum_{j=1}^{k} 2 \mathrm{jPDB}_{\mathrm{t}-\mathrm{j}}+\sum_{j=1}^{k} 2 \mathrm{jSBL}_{\mathrm{t}-\mathrm{j}}+\sum_{j=1}^{k} 2 \mathrm{jNTB}_{\mathrm{t}-\mathrm{j}}+2
\end{aligned}
$$




$$
\begin{aligned}
\mathrm{P}_{\mathrm{t}} & { }_{3}+\sum_{j=1}^{k} 3 \mathrm{jP}_{\mathrm{t}-\mathrm{j}}+\sum_{j=1}^{k} 3 \mathrm{jDB}_{\mathrm{t}-\mathrm{j}}+\sum_{j=1}^{k} 3 \mathrm{jSBL}_{\mathrm{t}-\mathrm{j}}+\sum_{j=1}^{k} 3 \mathrm{jNTB}_{\mathrm{t}-\mathrm{j}}+\sum_{j=1}^{k} 3 \mathrm{jNT}_{\mathrm{t}-\mathrm{j}} \\
& +3 \ldots \ldots \ldots \ldots \ldots \ldots \ldots \ldots \ldots . .(4.3) \\
\mathrm{PDB}_{\mathrm{t}}= & 4
\end{aligned}
$$

$$
\begin{aligned}
\mathrm{SBL}_{\mathrm{t}}= & { }_{5}+\sum_{j=1}^{k} 5 \mathrm{jSBL}_{\mathrm{t}-\mathrm{j}}+\sum_{j=1}^{k} 5 \mathrm{jNTB}_{\mathrm{t}-\mathrm{j}}+\sum_{j=1}^{k} 5 \mathrm{jNT}_{\mathrm{t}-\mathrm{j}}+\sum_{j=1}^{k} 5 \mathrm{jP}_{\mathrm{t}-\mathrm{j}}+\sum_{j=1}^{k} 5 \mathrm{jPDB}_{\mathrm{t}-\mathrm{j}} \\
& +5 \quad \ldots \ldots \ldots \ldots \ldots \ldots \ldots . .(6.3)
\end{aligned}
$$

NTB adalah Neraca transaksi berjalan, NT adalah Pertumbuhan Nilai Tukar Riil Rupiah yang didenominasikan dalam unit mata uang rupiah per unit mata uang $A S, P$ adalah Inflasi Indonesia dihitung dari perubahan IHK Indonesia, PDB adalah Pertumbuhan ekonomi (pertumbuhan output Indonesia berdasarkan PDB semua sektor berdasarkan harga konstan), dan SBL adalahSuku bunga LIBOR 6 bulan (suku bunga internasional). $t$ adalah kuartal, dan j adalah jumlah lag (kelambanan) kuartal yang dipilih berdasarkan estimasi terbaik. ${ }_{1 t}, \varepsilon_{2 t}, \varepsilon_{3 t}$, ${ }_{4 t}$ dan ${ }_{5 t}$ merupakan proses white noise (independen terhadap perilaku historis NTB, NT, P, PDB dan SBL).

\section{HASIL DAN PEMBAHASAN}

\section{Uji Akar-akar Unit}

Uji stasioneritas dapat dilakukan dengan uji akar-akar unit yang dikembangkan oleh Dickey Fuller. Alternatif dari uji Dickey Fuller adalah Augmented Dickey Fuller (ADF) yang berusaha meminimumkan autokorelasi. Uji ini berisi regresi dari diferensi pertama data runtut waktu terhadap lag variable tersebut, lagged difference terms, konstanta dan variable trend (Kuncoro, 2001). Untuk melihat uji stasioneritas dengan menggunakan uji DF atau ADF, dilakukan dengan membandingkan $t$ - statistik dari variable lag variable dependen dengan nilai kritis DF atau ADF dalam tabel. Data yang tidak stasioner bisa menyebabkan regresi yang lancung sehingga perlu dilakukan uji stasioneritas data. Hasil pengujian stasioneritas data untuk semua variable yang diteliti diperlihatkan pada Tabel 1.

Tabel 1. Hasil Pengujian Akar-akar Unit dengan Level

\begin{tabular}{|l|c|c|l|l|}
\hline \multicolumn{1}{|c|}{ Variabel } & $\begin{array}{c}\text { Nilai Augmented } \\
\text { Dickey-Fuller }\end{array}$ & $\begin{array}{c}\text { Nilai Kritis Mac Kinnon pada } \\
\text { Tingkat Signifikasi } \%\end{array}$ & Prob & Kesimpulan \\
\hline NTB & $-3,480786$ & $-3,592462$ & 0,0134 & Tidak Stasioner \\
\hline SBL & $-2,625404$ & $-3,615588$ & 0,0968 & Tidak Stasioner \\
\hline NT & $-4,666573$ & $-3,592462$ & 0,0005 & Stasioner \\
\hline P & $-1,461338$ & $-3,592462$ & 0,5434 & Tidak Stasioner \\
\hline PDB & $-1,537275$ & $-3,592462$ & 0,5054 & Tidak Stasioner \\
\hline
\end{tabular}

Sumber : Lampiran pengujian Unit Root test.

\section{Uji Lag Optimal}


Lag yang maximal didapat jika roots memiliki modulus lebih kecil dari satu dan semua terletak pada unit circle. Berdasarkan Tabel 2. Nilai Modulus seluruh akar unit berdasarkan pengujian stabilitas estimasi VAR memiliki modulus lebih kecil dari 1 (satu), sehingga estimasi VAR memenuhi kondisi stabil dengan menggunakan lag 2.

Tabel 2. Nilai Modulus Seluruh Akar Unit.

\begin{tabular}{ll}
\hline Roots of Characteristic Polynomial & \\
Endogenous variables: NTB SBL NT P PDB & \\
Exogenous variables: C & \\
Lag specification: 12 & \\
Date: $07 / 03 / 12$ Time: $16: 56$ & Modulus \\
\hline Root & 0.877107 \\
\hline $0.870332-0.108814 i$ & 0.877107 \\
$0.870332+0.108814 i$ & 0.757018 \\
$0.713810-0.252096 i$ & 0.757018 \\
$0.713810+0.252096 i$ & 0.539326 \\
$0.317848-0.435712 i$ & 0.539326 \\
$0.317848+0.435712 i$ & 0.446330 \\
$-0.139320-0.424029 i$ & 0.446330 \\
$-0.139320+0.424029 i$ & 0.179912 \\
-0.179912 & 0.130601 \\
0.130601 & \\
No root lies outside the unit circle. & \\
VAR satisfies the stability condition. & \\
\hline
\end{tabular}

Sumber : Data diolah dengan Eviews

\section{Uji Kointegrasi}

Dari hasil uji Kointegrasi yang dilakukan terlihat bahwa nilai hitung Trace Statistic dan maksimum Eigenvalue lebih besar daripada nilai kritisnya, maka terdapat kointegrasi pada sejumlah variabel. Berdasarkan hasil uji kointegrasi seperti yang terlihat Tabel 3 diketahui bahwa ada 5 persamaan kointegrasi pada level 5\%. Dan nilai-nilai dari Trace statistic dan maximum eigenvalue lebih besar dari nilai Critical value, yang berarti adanya hubungan jangka panjang antara variable terbukti.

Tabel 4.9 Uji Kointegrasi Johansen

\begin{tabular}{|c|c|c|c|c|}
\hline \multicolumn{5}{|c|}{ Date: 07/19/12 Time: 11:50 } \\
\hline \multicolumn{5}{|c|}{ Sample (adjusted): 2000Q3 2010Q4 } \\
\hline \multirow{2}{*}{\multicolumn{5}{|c|}{$\begin{array}{l}\text { Included observations: } 42 \text { after djustments } \\
\text { Trend assumption: Linear deterministic trend } \\
\text { Series: NTB SBL NT P PDB } \\
\text { Lags interval (in first differences): } 1 \text { to } 1 \\
\text { Unrestricted Cointegration Rank Test (Trace) }\end{array}$}} \\
\hline & & & & \\
\hline $\begin{array}{c}\text { Hypothesized } \\
\text { No. of } C E(s)\end{array}$ & Eigenvalue & $\begin{array}{c}\text { Trace } \\
\text { Statistic }\end{array}$ & $\begin{array}{c}0.05 \\
\text { Critical Value } \\
\end{array}$ & Prob.** \\
\hline $\begin{array}{c}\text { None } \\
\text { At most } 1\end{array}$ & $\begin{array}{l}0.547033 \\
0.306528\end{array}$ & $\begin{array}{l}68.22038 \\
34.95903\end{array}$ & $\begin{array}{l}69.81889 \\
47.85613\end{array}$ & $\begin{array}{l}0.0666 \\
0.4502\end{array}$ \\
\hline At most 2 & 0.238345 & 19.58516 & 29.79707 & 0.4514 \\
\hline
\end{tabular}




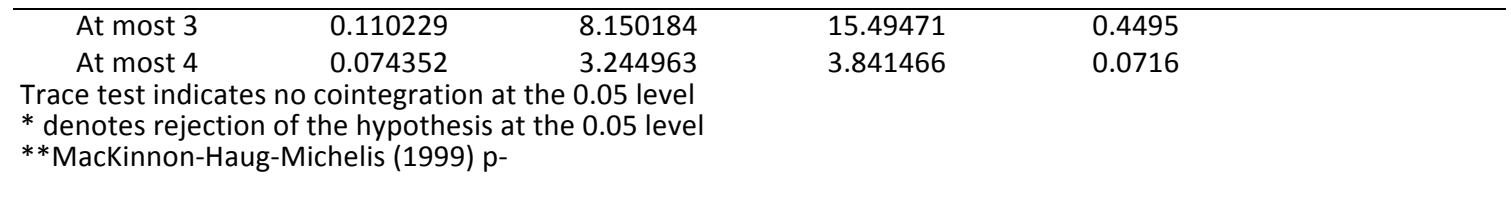

Sumber : Data di olah dengan Eviews

\section{Vector Autoregression (VAR)}

Estimasi VAR didukung dengan penggunaan lag, pemilihan lag yang digunakan ditentukan oleh lag optimal. Stabilitas VAR dilihat dari nilai Inverse roots karakteristik AR polinominalnya.

Berdasarkan hasil estimasi VAR diperoleh hasil bahwa:

1. Variabel Neraca Transaksi Berjalan, kontribusi yang paling besar dan positif terhadap NTB adalah NTB itu sendiri sebesar 2,368. Disusul oleh Indeks harga/Inflasi sebesar 1,956, kemudian Nilai Tukar Rupiah terhadap US Dolar sebesar 1,236. Sedangkan variable lain seperti Suku bunga Libor 6 bulan dan PDB pengaruhnya tidak begitu besar terhadap NTB hanya sebesar 0,766 terhadap SBL dan 0,416 terhadap PDB.

2. Variabel Nilai Tukar, kontribusi yang paling besar dan positif terhadap Nilai Tukar adalah Suku Bunga Libor 6 bulan sebesar 3,238. Sedangkan variable yang lain tidak begitu besar bahkan nilainya kurang dari satu. Dimana untuk Nilai Tukar itu sendiri sebesar 0,959, PDB sebesar -0,125, Indeks harga/inflasi sebesar -0,129, dan neraca transaksi berjalan sebesar $-0,786$ pengaruhnya terhadap variable Nilai Tukar Rupiah terhadap US Dolar.

3. Indeks Harga/Inflasi, kontribusi yang paling besar dan positif terhadap Indeks Harga/Inflasi adalah Indeks Harga/Inflasi itu sendiri sebesar 2,687, sedangkan variable yang lain seperti NTB, Nilai Tukar, Suku Bunga Libor dan PDB pengaruhnya tidak begitu besar, bahkan nilainya dibawah 1 (satu).

4. Pertumbuhan Output (PDB), kontribusi yang paling besar dan positif terhadap PDB adalah PDB itu sendiri sebesar 3,91, sedangkan variable yang lain pengaruhnya tidak begitu besar bahkan kurang dari 1 (satu), yaitu variabel NTB, Nilai Tukar, Suku Bunga Libor dan Infalasi/Indeks harga.

5. Suku Bunga Libor 6 bulan, kontribusi yang paling besar dan positif terhadap Suku Bunga Libor 6 bulan adalah variable Suku Bunga itu sendiri sebesar 5,618, sedangkan variable yang lain pengaruhnya tidak begitu besar bahkan kurang dari 1 (satu), yaitu variable Neraca transaksi Berjalan, Nilai Tukar, SBL dan PDB.

\section{Impulse Response Function Neraca Transaksi Berjalan (NTB)}

Dalam periode jangka pendek pengaruh satu unit standar deviasi SBL 6 Bulan, Inflasi/Indeks Harga dan pertumbuhan ekonomi (PDB) terhadap satu standar deviasi NTB adalah positif, sedangkan satu unit standar deviasi NTB dan Nilai tukar terhadap satu unit standar deviasi NTB adalah negatif. 
Dalam periode jangka panjang pengaruh satu unit standar deviasi PDB tyerhadap satu unit standar deviasi NTB adalah positif, sedangkan satu unit standar deviasi NTB, SBL, Nilai Tukar dan Inflasi (IHK) terhadap satu unit standar deviasi neraca transaksi berjalan adalah negatif.

\section{Impulse Response Function Nilai Tukar (NT)}

Dalam periode jangka pendek pengaruh satu unit standar deviasi Suku Bunga Libor 6 Bulan dan PDB terhadap satu standar deviasi Nilai Tukar adalah positif, sedangkan satu unit standar deviasi Neraca transaksi Berjalan, Nilai tukar dan Inflasi terhadap satu unit standar deviasi Nilai Tukar adalah negatif.

Dalam periode jangka panjang pengaruh satu unit standar deviasi PDB terhadap satu unit standar deviasi Nilai Tukar adalah positif, sedangkan satu unit standar deviasi Neraca transaksi Berjalan, Suku Bunga Libor, Nilai Tukar dan Inflasi(IHK) terhadap satu unit standar deviasi Nilai Tukar adalah negatif.

\section{Impulse Response Function Inflasi/Indeks harga (P)}

Untuk variable Inflasi yang dilihat dari Indeks harga terlihat bahwa dalam jangka pendek pengaruh satu unit standar deviasi Neraca Transaksi Berjalan, Suku Bunga Lobir, Nilai Tukar dan Infalasi terhadap satu unit standar deviasi Inflasi adalah positif. Sedangkan satu unit standar deviasi PDB terhadap satu unit standar deviasi inflasi/Indeks Harga adalah negatif.

Dalam periode jangka panjang pengaruh satu unit standar deviasi Neraca transaksi Berjalan dan Suku Bunga Libor terhadap satu unit standar deviasi Inflasi/Indeks Harga adalah positif, sedangkan satu unit standar deviasi Nilai Tukar, Inflasi/indeks Harga dan PDB terhadap satu unit standar deviasi Inflasi/Indeks Harga adalah negative. Dalam jangka pendek pengaruh satu unit standar deviasi Suku Bunga Lobir dan PDB terhadap satu unit standar deviasi PDB adalah positif. Sedangkan satu unit standar deviasi Neraca transaksi Berjalan, Nilai Tukat dan Inflasi (P) terhadap satu unit standar deviasi PDB adalah negatif. Dalam periode jangka panjang pengaruh satu unit standar deviasi Nilai Tukar terhadap satu unit standar deviasi PDB adalah positif, sedangkan satu unit standar deviasi Neraca transaksi berjalan, Suku Bunga labor, Inflasi/indeks Harga dan PDB terhadap satu unit standar deviasi PDB adalah negative.

\section{Impulse Response Function Suku Bunga labor (SBL)}

Dalam periode jangka pendek pengaruh satu unit standar deviasi Suku Bunga Libor 6 Bulan dan PDB terhadap satu standar deviasi Suku Bunga Libor adalah positif, sedangkan satu unit standar deviasi Neraca transaksi Berjalan, Nilai tukar dan Inflasi terhadap satu unit standar deviasi Suku Bunga Libor adalah negative.

Kestabilan respon dari Neraca transaksi berjalan terhadap variable NTB itu sendiri, SBL, NT, Inflasi (P) dan PDB dicapai pada kuartal kesepuluh atau dalam jangka panjang.

Dari hasil Impulse response function terlihat dalam periode jangka panjang pengaruh satu unit standar deviasi PDB terhadap satu unit standar deviasi Suku Bunga Libor adalah positif, sedangkan satu unit standar deviasi Neraca transaksi Berjalan, Suku 
Bunga Libor, Nilai Tukar dan Inflasi (IHK) terhadap satu unit standar deviasi Suku Bunga Libor adalah negatif.

\section{Analisis Variance Decomposition Neraca Transaksi Berjalan}

Dalam periode jangka pendek perkiraan error variance dijelaskan oleh Neraca transaksi Berjalan (NTB) sebesar 86,73 persen, di ikuti oleh Inflasi/Indeks Harga sebesar 6,94 persen, PDB sebesar 3.09 persen, Nilai Tukar 2,09 persen dan Suku Bunga Libor 1,13 persen. Dalam periode jangka panjang perkiraan error variance dijelaskan oleh NTB sebesar 80,85 persen, di ikuti oleh inflasi/Indeks harga 7,29 persen, Suku Bunga Libor 6,54 persen PDB 3,24 persen dan Nilai Tukar 2.06 persen.

Pada perode jangka pendek dan jangka panjang variable Neraca transaksi Berjalan (NTB) secara dominan berubah oleh Neraca transaksi Berjalan itu sendiri. Hal ini berarti bahwa kejutan dari variable lain memiliki kemampuan yang kecil terhadap pertumbuhan Neraca transaksi berjalan.

\section{Analisis Variance Decomposition Nilai Tukar}

Dalam periode jangka pendek perkiraan error variance dijelaskan oleh Nilai Tukar sebesar 34,01 persen, di ikuti oleh NTB sebesar 33,39 persen, SBL sebesar 25,68 persen, PDB 6,27 persen dan Inflasi (P) 0,63 persen. Dalam periode jangka panjang perkiraan error variance dijelaskan oleh Nilai Tukar sebesar 29,35 persen, di ikuti oleh NTB sebesar 27,94 persen, SBL sebesar 21,51 persen, PDB 10,98 persen dan Inflasi (P) 10,19 persen. Pada perode jangka pendek dan jangka panjang variable Neraca Transaksi Berjalan (NTB) secara dominan berubah oleh Neraca transaksi Berjalan itu sendiri. Meskipun dalam jangka panjang kejutan dari masing-masing variable terhadap pertumbuhan NT hampir sama yaitu dengan rata-rata 30-10 persen. Hal ini berarti bahwa dalam jangka panjang kejutan semua variable memiliki pengaruh hampir sama terhadap pertumbuhan Nilai Tukar.

\section{Analisis Variance Decomposition Inflasi}

Dalam periode jangka pendek perkiraan error variance dijelaskan oleh Inflasi (P) sebesar 58,22 persen, di ikuti oleh NTB sebesar 27,99 persen, Nilai Tukar sebesar 9,89 persen, PDB 6,27 persen dan PDB 1,67 persen. Dalam periode jangka panjang perkiraan error variance dijelaskan oleh Inflasi (P) sebesar 48,30 persen, di ikuti oleh NTB sebesar 18,11 persen, SBL sebesar 15,64 persen, Nilai Tukar 9,34 persen dan PDB 8,58 persen .

Pada periode jangka pendek dan jangka panjang variable Inflasi $(P)$ secara dominan berubah oleh Inflasi/Indeks harga $(P)$ itu sendiri..Dalam jangka panjang variable lain NTB, NT, SBL dan PDB memberikan kejutan antara 18 - 8 persen terhadap pertumbuhan Inflasi.

\section{Analisis Variance Decomposition PDB}


Dalam periode jangka pendek perkiraan error variance dijelaskan oleh PDB sebesar 54,09 persen, di ikuti oleh Inflasi (P) sebesar 24,59 persen, NTB sebesar 12,74 persen, NT 6,0 persen dan SBL 2,55 persen. Dalam periode jangka panjang perkiraan error variance dijelaskan oleh PDB sebesar 42,39 persen, diikuti oleh Inflasi (P) sebesar 27,32 persen, NTB sebesar 13,79 persen, SBL sebesar 10,54 persen dan Nilai Tukar 6,93 persen. Pada perode jangka pendek dan jangka panjang variable PDB secara dominan berubah oleh PDB itu sendiri.

\section{Analisis Variance Decomposition SBL}

Dalam periode jangka pendek perkiraan error variance dijelaskan oleh SBL sebesar 92,29 persen, di ikuti oleh NTB sebesar 4,45 persen, NT sebesar 2,21 persen, Inflasi (P) 0,78 persen dan PDB 0,24 persen. Dalam periode jangka panjang perkiraan error variance dijelaskan oleh SBL sebesar 69,74 persen, diikuti oleh PDB sebesar 10,88 persen, Inflasi (P) sebesar 9,94 persen, NT sebesar 5,39 persen dan NTB 4,03 persen.

Pada perode jangka pendek dan jangka panjang variable PDB secara dominan berubah oleh PDB itu sendiri. Pada periode jangka pendek pengaruh dari variable lain seperti NTB, NT, Inflasi (P) dan PDB memberi pengaruh kejutan yang sangat kecil sekali terhadap pertumbuhan SBL, namun pada periode jangka panjang pengaruh kejutan dari variable tersebut mulai meningkat terhadap pertumbuhan Suku Bunga Libor.

Output Variance Decomposition dari semua variable penelitian menjelaskan bahwa variance variable memberi kontribusi variable itu sendiri baik dalam jangka pendek maupun jangka panjang. Terjadi perubahan kontribusi variance yang semakin menurun terhadap variable itu sendiri dalam jangka panjang. Hal ini berarti bahwa dalam jangka panjang kontribusi variance dari masing masing variable member kejutan yang semakin besar terhadap variable Neraca Transaksi Berjalan.

\section{KESIMPULAN DAN SARAN}

\section{Kesimpulan}

Penelitian ini mengkaji mengenai pengaruh kejutan pertumbuhan Neraca transaksi berjalan (NTB) terhadap variable Nilai tukar (NT), Inflasi (P), Suku Bunga Libor (SBL), dan Pertumbuhan Ekonomi (PDB) selama periode 2000.1 sampai dengan 2010.4 di Indonesia. Berdasarkan hasil penelitian yang telah dilakukan maka diperoleh beberapa kesimpulan berikut:

a. Perkembangan Neraca transaksi Berjalan selama Periode penelitian terus mengalami fluktuasi berkisar antara 1 - 2 milyar US Dollar, sedangkan nilai tukar rata-rata Rupiah terhadap US Dollar selama perode penelitian dikatakan berada pada posisi Rp.7.000,00 - Rp. 10.000,00. Per US Dollar, dan Suku Bunga Libor selama periode penelitian sangat berfluktuasi sekali bahkan di tahun $2010 \mathrm{SBL}$ berada di posisi nol koma. Dan Inflasi yang di lihat dari Indeks harga Konsumen 
selama periode penelitian berkisar antara 100 - 200 persen. Sedangkan PDB selama perione penelitian terus mengalami peningkatan.

b. Hasil dari Estimasi Vector Aoturegression ( VAR ) menunjukkan bahwa variable yang sifnifikan mengkontribusi Neraca Transaksi berjalan adalah NTB itu sendiri, Nilai Tukar (NT) dan Inflasi (P). dengan kontribusi positif, sedangkan variable lain SBL dan PDB kontribusinya kurang dari satu terhadap Neraca transaksi Berjalan (NTB). Sedangkan kontribusi yang diberikan NTB terhadap variable lain sangat kecil kecuali terhadap NTB itu sendiri, bahkan dengan magnitude yang sangat besar selama periode penelitian ini.

c. Output Impulse Response Function menunjukkan kondisi bahwa dalam jangka pendek perubahan Neraca transaksi berjalan (NTB) direspon positif paling besar oleh PDB, Inflasi (P) dan Suku Bunga Libor (SBL). Dalam jangka panjang hampir semua impulse response fuction bernilai negative, kecuali PDB yang masih positif meskipun IRF nya menurun. Sebaliknya NTB merespon negative paling besar terhadap perubahan Nilai Tukar (NT) dalam jangka pendek.

d. Respon NT terhadap NTB baik dalam jangka pendek maupun jangka penjang memberi pengaruh negative, hal ini sesuai dengan teori yang menyatakan apabila nilai tukar terdepresiasi maka impor akan turun dan ekspor akan naik, Nilai NTB juga akan naik. Demikian pula respon dari NTB terhadap NT juga berpengaruh negative.

e. Respon SBL terhadap NTB dalam jangka pendek berpengaruh positif sedangkan dalam jangka pajang berpengaruh negative. Sebaliknya respon NTB terhadap SBL berpengaruh negative baik dalam jangka pendek maupun jangka panjang. Hal ini berarti kenaikan suku bunga akan membuat posisi neraca transaksi berjalan menurun, karena investor lebih tertarik berinvestasi pada sektor keuangan dari pada investasi riil.

f. Respon Inflasi (P) terhadap NTB dalam jangka pendek berpengaruh positif, dan dalam jangka panjang berpengaruh negative, sedangkan respon NTB terhadap Inflasi (P) berpengaruh positif namun semakin menurun dalam jangka panjang. Ini berarti bahwa inflasi dalam jangka panjang akan memperburuk kondisi neraca transaksi berjalan.

g. Respon PDB terhadap NTB baik dalam jangka pendek maupun jangka panjang adalah positif, Sedangkan respon NTB terhadap PDB dalam jangka pendek juga positif, namun dalam jangka panjang negative. Ini berarti bahwa Pertumbuhan PDB dalam jangka panjang akan membuat kondisi neraca transaksi berjalan memburuk, namun dalam jangka pendek peningkatan PDB juga akan meningatkan NTB.

h. Output dari Variance decomposition menunjukkan bahwa Neraca Transaksi Berjalan (NTB) cenderung sebagai variable yang menerima kontribusi dari pada memberi kontribusi. 
Andriani, Prima. (2008), Analisis Pengaruh Neraca Perdagangan dan Capital Inflow terhadap pertumbuhan Ekonomi di Indonesia, Skripsi tidak diterbitkan, Fakultas Ekonomi dan Manajemen, IPB.

Bank Indonesia, (2000 - 2010), Laporan Tahunan Ekonomi, Publikasi, www.bi.co.id.

Bank Indonesia (2000 - 2011 ) Statistik Ekonomi Keuangan Indonesia, Berbagai Edisi.

Boediono (1999), Ekonomi Moneter, Edisi 3, Yokyakarta, BPFE.

Boediono, (1994), “Merenungkan Kembali Mekanisme Transmisi Moneter di Indonesia", Buletin Ekonomi Moneter dan Perbankan, Bank Indonesia.

Darwanto, (2007), Kejutan Pertumbuhan nilai Tukat Riil terhadap Inflasi, Pertumbuhan output, dan Pertumbuhan Neraca transaksi berjalan di Indonesia 1983.1- 2005. Jurnal Ekonomi Pembangunan, Kajian Ekonomi Negara berkembang, Vol 12, No. 1.

Enders, W. (2004), Applied Econometric Time Series, Second edition, John Wiley\& Sony Inc.

Fuat Lebe, Slim Kahn, Uĝur Adigủzel, (2009), The Empirical Analisys of The Effect of Economic growth and Exchange rate on Current Account Defisit ; Romania and Turkey Samples, Journal of Appliede Quantitative, methods. Vol. 4 No. 1. Spring 2009.

Gujarati, Damodar N. (2003), Basic Econometric, 4th Edition, McGraw-Hill.

Haris, Richard (1995), Cointegration Analysis in Econometric Modeling, Prentice Hall.

Krenein, Mordechai. E, (2002), International Economics ; A Policy Approach, Thomson Learning.

Krugman, Paul R, and Maurice Obstefld, 1999, Ekonomi Internasional (Teori dan Kebijakan ), Edisi kedua, PT Raja Grafindo Persada, Jakarta.

Madura, Jeff (1999), International Financial Management, USA: South-Western College Publishing.

Mankiw, G.N. (2003), Macroeconomics, 5th Edition, Worth.

Mankiw, G.N, (2006), Macroeconomi, Edisi keenam, Erlangga, Jakarta

Michael Todaro (2000), Ekonomi untuk Negara Berkembang, suatu pengantar, Bumi Aksara.

Michael P,Todaro (1978), Pembangunan Ekonomi Dunia Ketiga, alih bahasa Aminuddin, Drs, Mursid, Ghalia Indonesia, Jakarta, 1983.

Murti. Hari, (2007) ,Analisis Jangka Pendek dan Jangka Panjang Diterminan Neraca Transaksu Berjalan serta Fenomena Twin Deficit di Asia Tenggara dan Asia Selatan, Jurnal Ilmu Ekonomi dan Pembangunan, Vol, 7 No. 1.

Onafowora, O. (2003), Exchange Rate and Trade Balance In East Asia: Is There a Jcurve, Economics Bulletin, http://.economicsbuletin.com /2003/volume5. 
Phillips.P.C.B dan Perron.P, (1988), Testing For a Unit Root in Time Series Regresion, Biometrika.

Pugel, Thomas A. (2004), International Economics, 12th Edition, Irwin McGraw- Hill.

Raharja, Sanityasa. (2011), Analisis Faktor-faktor Yang Mempengaruhi Tingkat Bunga Deposito Bank Umum di Indonesia, Skripsi tidak diterbitkan, Fakultas Ekonomi Universitas Diponegoro, Semarang.

Salvatore, Dominick . (1996) . Drs. Harris Munandar (Ed). 1997. Ekonomi Internasional, Erlangga, Jakarta.

Santosa, Agus Budi (2010), Pengaruh Fluktuasi Nilai Tukar Rupiah terhadap Neraca transaksi Berjalan, Dinamika Keuangan dan Perbankan, Vol 2 No.2, Hal $169-181$.

Sims, C.A. (1980), Are Forecasting Models Usable for Policy Analysis?, Federal Reserve Bank of Minneapolis Quarerly Review.

Sukirno, Sadono. (1994). Pengantar Teori Makroekonomi. Jakarta: Rajawali Press.

Sukirno, Sadono (2000). Makro Ekonomi Modren, Perkembangan Pemikiran dari Klasik hingga Keynesian Baru, PT. Raja Grafindo, Jakarta.

Tambunan. Tulus, (2001), Perdagangan Internasional dan Neraca Pembayaran, Ghalia Indonesia, Jakarta.

Tambunan, Tulus. (2001a), Perekonomian Indonesia, Teori dan Terapan Em,piris, Ghalia Indonesia, Jakarta.

Thomas, RL, (1997). Modern Econometrics: An Introduction, Adison Wesley.

Wang, Peiji (2003), Financial Econometrics, Method and Models, Routledge Taylor \& Francis Group. 81

Widyastutik dan Yusuf, (2007). Analisis Pengaruh Ekspo-Impor komoditas pengan utama dan liberalisasi Perdagangan terhadap Neraca Perdagangan Indonesia, Jurnal Management Agrobisnis, Vol 4 No.1. $46-56$.

W. Nasruddin, (2002), Inflasi (Demand Full and Cost Push Inflation), Kumpulan Paper Makro Ekonomi Lanjutan, Program Studi Ekonomi Pertanian, 